\title{
Second-hand consumption as a way of life: public auctions in the surroundings of Alost in the late eighteenth century
}

\author{
ILJA VAN DAMME AND REINOUD VERMOESEN*
}

ABSTRACT. This article seeks to place second-hand consumption, or the reuse of older objects, into the expanding historical literature on early modern consumer practices. It claims that the study of second-hand consumption remains a much neglected topic of historical interest. Further empirical research of pre-industrial reuse habits is needed to examine essential problems and inconsistencies concerning consumers and their handling of older goods. On the basis of rarely used sources relating to public auctions in the countryside of the southern Netherlands, key questions regarding the current debate will be addressed. These questions concern the products that were handled, the actors involved, and how reuse was (or was not) affected by broader changes in society.

Why would people consume second-hand products? This simple question unlocks a complex and dazzling area of research in which economic and social structures meet culturally biased material consumption. Oddly enough, the reuse of old and discarded objects in the past has received only minor attention from consumer historians. Studies of consumption connect to mainstream historical understanding, but they tend to analyse predominantly the acquisition of new goods (such as the use of imported cotton and porcelain) and the rise of novel consumption patterns (such as tea-drinking and tobacco-smoking). ${ }^{1}$ Thus far, historians have studied second-hand consumption mainly as an aspect of developments in the production of textiles. ${ }^{2}$ Not surprisingly, the widespread use of secondhand clothing in the past has made these practices all the more visible

\footnotetext{
* Both of the Centre for Urban History, University of Antwerp.
} 
through different sources, such as commercial documents, civil lawsuits, municipal legislation, and advertisements. ${ }^{3}$ Beverly Lemire, in particular, has observed the trade in second-hand clothing and regards it as an essential element of the early modern retail infrastructure. ${ }^{4} \mathrm{Her}$ studies have been influential in signalling diverse commercial circuits of professionals - both specialist and non-specialist, formal and informal who scavenged the streets in search of clothes and rags. Guild-organized dealers, shop sellers, pawnbrokers and hawkers on the fringes of the legal economy, as well as fences for stolen goods, became the focus of historical attention. ${ }^{5}$ The reuse of textiles became better known, but an understanding of second-hand dealings has in general remained the subject of speculation. ${ }^{6}$ Second-hand consumption is too often regarded as merely a survival strategy.

This article cannot address every question that remains unanswered in the historiography. Nor will it offer an overview of the existing evidence regarding the use of second-hand consumption in early modern times. Our endeavour is a limited, and empirically structured case study, isolated in space and time. Yet in placing second-hand consumption in a specific context, we demonstrate how the reuse of older products was not confined to the poor and the weak. Second-hand consumption was intrinsically linked to daily life in the ancien régime. Naturally, the reasons for secondhand consumption depended on the particular product, individual motives, and the goals of the households involved. Indeed, this study reconsiders the utility of the second-hand products in question. Thus, we look first at the sorts of goods that were reused. Although clothing is considered a highly important second-hand product - hence justifying its central role in historical literature - consumption of other objects extended to pots and pans, furniture, bedding, and even luxury goods. Secondly, we consider the sellers and buyers of these second-hand objects, and we speculate about their reasons for such activities. Did practices of reuse centre solely around survival strategies, or can we interpret them as a meaningful consumer strategy for almost every pre-industrial household? Finally, did eighteenth-century alterations in taste and in demand affect the value of the reused products under study and the social composition of the groups that engaged in this process? Acknowledging second-hand consumption as a much neglected 'consumer flow' that reflects broader historical evolutions provides a welcome alternative to consumer accounts dominated by probate inventories. ${ }^{7}$

The time and place under consideration here are both highly suitable for these questions. Although our data apply only to a tiny village, Erembodegem, in the Flemish countryside, it was hardly located in an obscure region of Europe (see Map 1). Franklin Mendels's influential 


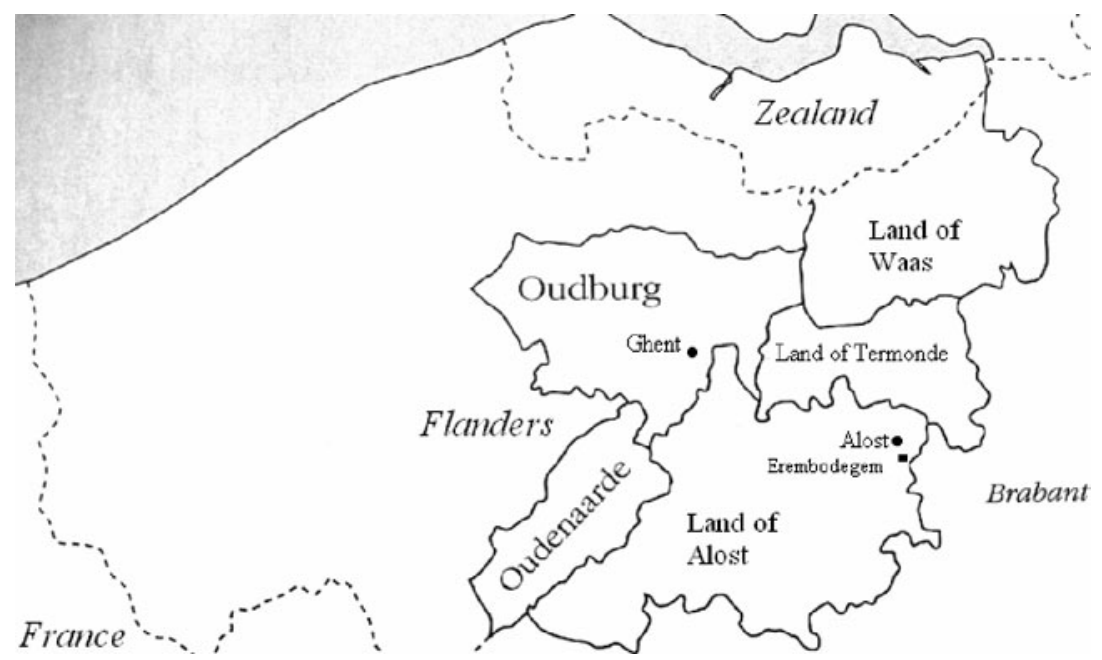

MAP 1. Flanders in the eighteenth century, showing the location of the village of Erembodegem near Alost (Aalst). (Source: R. Vermoesen, 'Een bres in de muur: functie van de wallen in de regionaal-economische ontwikkeling: houding van de Aalsterse economische actoren tijdens de oorlogen van Lodewijk XIV (1667-1714)', in R. Fagel and D. Onnekink eds., Oorlog en Samenleving in de Nieuwe Tijd (Maastricht, 2005), 61-80.)

thesis on proto-industrialization was based on this part of Flanders. ${ }^{8}$ Thus, examining second-hand dealings in Erembodegem at the end of the eighteenth century offers insights into the consumer practices of an important rural society in transition. Until now, studies of consumerism and consumption patterns in the southern Netherlands have centred too narrowly on urban areas, leading some authors to believe with Erik Thoen that 'any creative [consumer] force from the countryside which might stimulate production or trade' was simply absent in this period. ${ }^{9}$ In particular, rural households, embedded in the peasant economy or 'commercial survival economy' of southeast Flanders, are believed to have lacked the ability to participate in the increasing economic prosperity of the eighteenth century. Important features of this region include impressive population growth during the period, accompanied by high population density. Most households were owners of their real estate, but up to 90 per cent of the families possessed less than 5 hectares. It was therefore necessary for them to engage in by-employments, including spinning and linen-weaving. ${ }^{10}$ Gaining a better understanding of this kind of countryside consumer is the object of this article. Focusing on the second-hand practices of village households, we argue, is a crucial key to achieving this goal. Our research fits into the expanding literature on the 
aspirations of rural households and families in times of protoindustrialization. ${ }^{11}$

Our document source is a group of public auctions (so-called 'vendities'). Thus, one particular segment of the overall second-hand market is analysed in depth in this article. These neglected auction records were compiled at the same time as, or just after, an inventory was made of the belongings of a deceased person. The sources indicate a common early modern practice of selling some of the deceased's possessions, and sometimes even all the furniture, trading stock, debentures and annuities, and other goods, generally when an individual died intestate. ${ }^{12}$ These auctions were organized on a voluntary basis by the heirs or legatees of the deceased, or they were required by customary law (costuimen) in Flanders when conflicts arose regarding the succession to moveable property. ${ }^{13}$ When an auction followed the death of a widow(er), the extended family normally decided to sell all the household effects. ${ }^{14}$ Usually, the heirs claimed some property before the auction, but if a dispute arose, an auction was arranged so that the proceeds from a particular sale could be shared equally among the heirs or legatees (or among the creditors, to settle debts). Everyone was free to buy at these auctions. During the actual bidding the heirs could still purchase a particular item. ${ }^{15}$ Indeed, heirs could even bid against each other. At such times, other prospective buyers, from outside the family, would refrain from bidding out of social considerations or out of respect for the deceased. ${ }^{16}$

Until recently, these documents have been rarely used, yet they provide a wealth of information on actual changes in ownership of older goods. ${ }^{17}$ From a detailed study of all the probate inventories drawn up in the years 1750-1759 and 1785-1794 in Erembodegem, we found a total of 41 vendities. ${ }^{18}$ Our first sample contained 102 inventories, of which 25 resulted in public auctions. The latter sample included 105 inventories and 16 vendities. From these sources we gathered information about the sellers and the households that were discarding objects; the products offered (sold in so-called auction lots); the prices fetched; and the buyers of the reused products. These data were matched with tax lists (the so-called settingen) and a demographic source, the status animarum, in order to connect sellers and buyers at the auctions with their respective fiscal and geographical backgrounds. This analysis was hitherto not possible for other contexts in the southern Netherlands. ${ }^{19}$

The first question to consider in our study of the records of public auctions in Erembodegem concerned the resold goods: what used belongings 


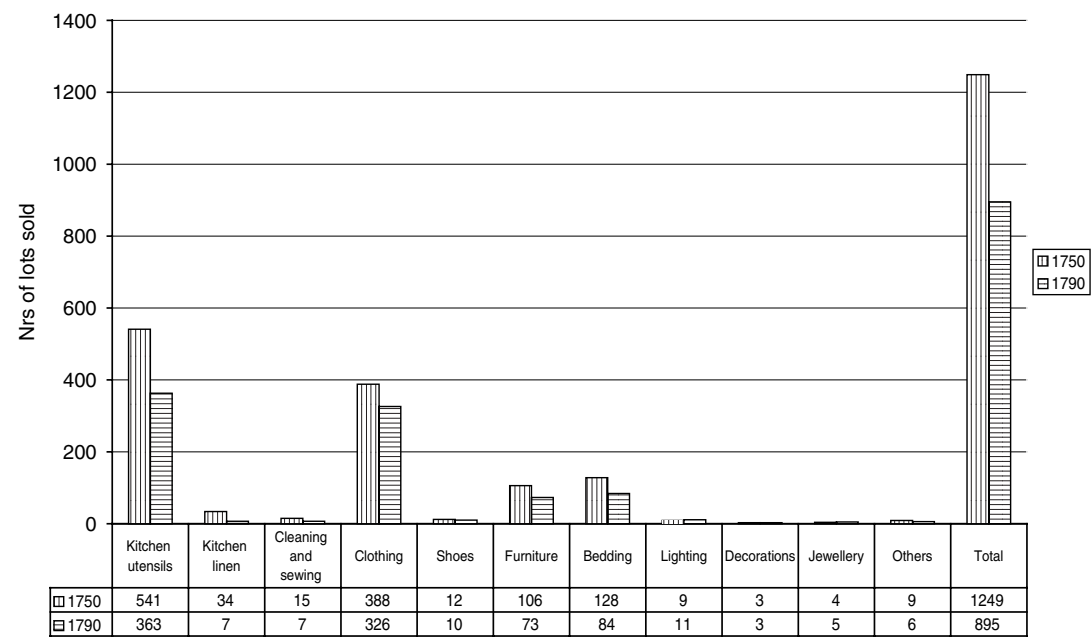

FIGURE 1. Second-hand goods sold at the vendities in Erembodegem, 1750-1759 and 1785-1794, by category. (Source: Unpublished database based on Municipal Archives Alost, Oud Archief Erembodegem, staten van goed, nrs 1369-78 and 1404-13, and settingen, nrs 251 and 255.)

were actually sold and at what prices? To answer these questions, we clustered all individual objects into transparent product categories that were common to early modern consumer studies. ${ }^{20}$ Thus, stockings, shirts, handkerchiefs, and the like were clustered under the heading 'clothing'; pots and pans and all kitchen-related goods were placed under the product category 'kitchen utensils'; bedsteads, bedlinen, and pillows were grouped under 'bedding'; and so on. ${ }^{21}$ The total number of transactions or auction lots in the 1750 s auctions decreased by 28 per cent in half a century, representing a drop in the value of the goods auctioned of 33 per cent. $^{22}$ The total population of Erembodegem was rising during this period, and the ratio of auctions to the general population increased likewise: from one transaction per 1.5 inhabitants in the 1750 s to one transaction per 2.5 inhabitants at century's end. ${ }^{23}$ This decline in both the total volume of transactions and the overall sale value of goods that were auctioned must be kept in mind. Arguably, it indicates important changes in the auctioning of second-hand products during the period.

The composition of the auctioned goods, however, shows remarkable continuity. The categories 'kitchen utensils' and 'clothing' were clearly the most sought-after auction items in the second half of the eighteenth century (see Figures 1-3). Nevertheless, our data suggest that nearly every type of goods in the households of Erembodegem could be, and was, 


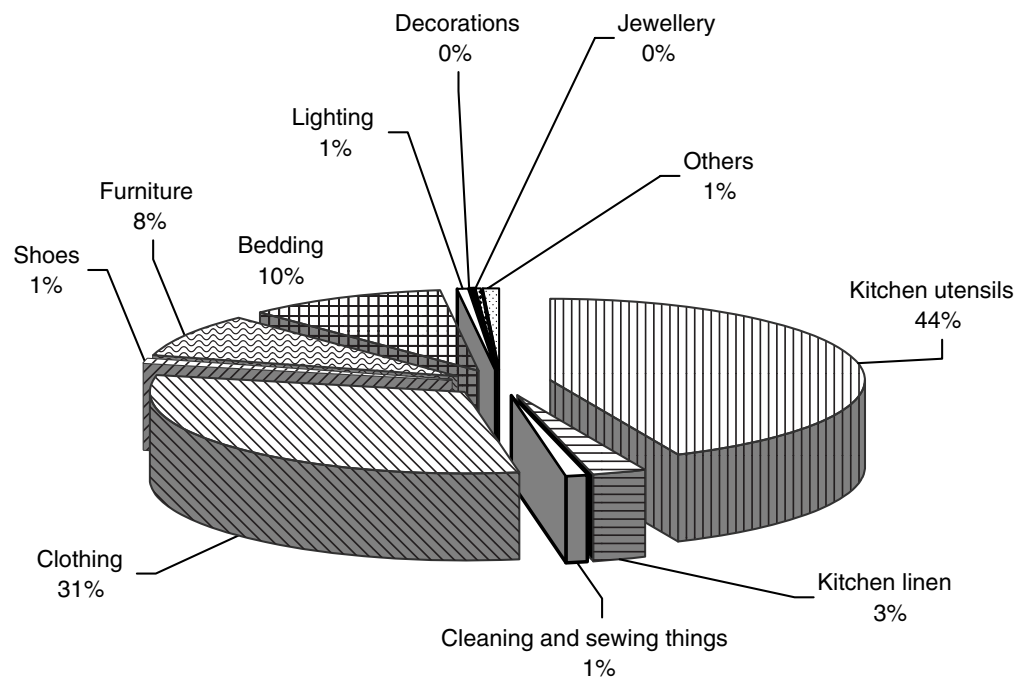

FIGURE 2. Second-hand goods sold at the vendities in Erembodegem, 1750-1759, by category (\%). (Source: See Figure 1.)

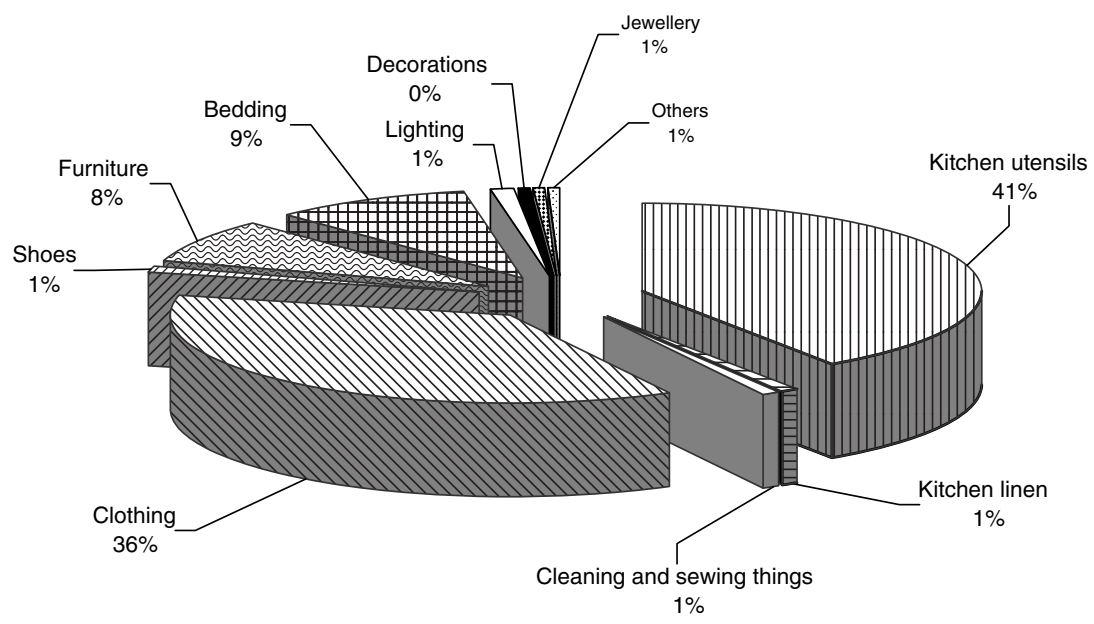

FIGURE 3. Second-hand goods sold at the vendities in Erembodegem, 1785-1794, by category (\%). (Source: See Figure 1.) 


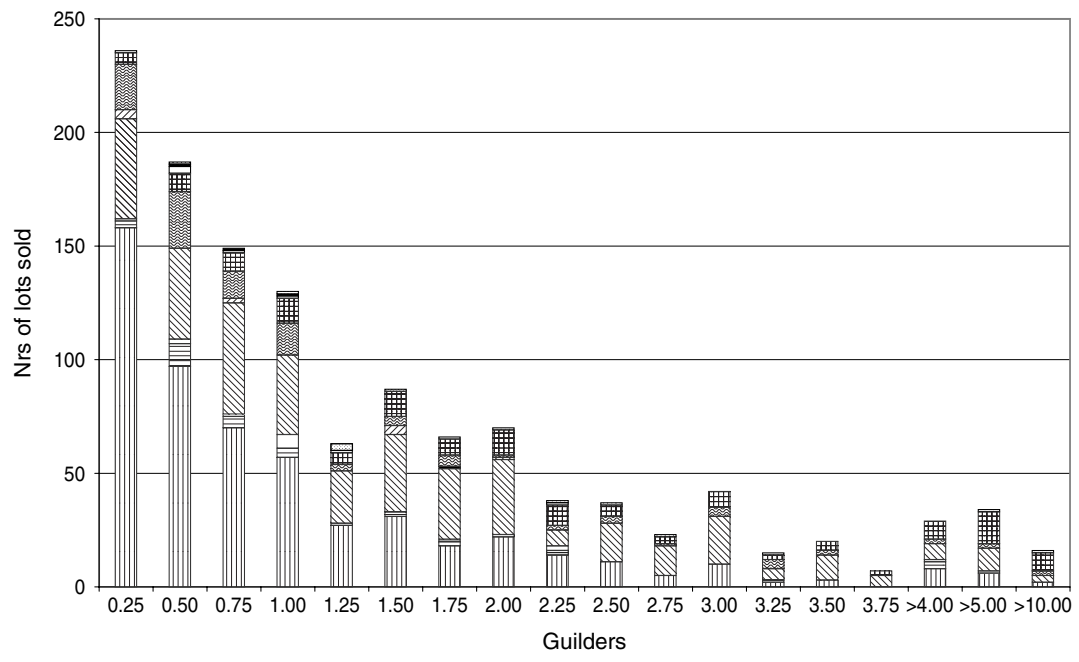

$\square$ Kitchen utensils $\boxminus$ Kitchen linen $\square$ Cleaning and sewing things $\square$ Clothing $\square$ Shoes 当 Furniture

田 Bedding $\square$ Lighting Decorations 团 Jewellery $\square$ Others

FIGURE 4. Second-hand goods sold at the vendities in Erembodegem, 1750-1759, by price and category. (Source: See Figure 1.)

auctioned in the second half of the eighteenth century, although luxury items were rarely auctioned. The 'furniture' category, for instance, consisted of plain wooden tables, benches, chairs, cupboards, and chests (and one standing clock, c. 1790), clearly reflecting the rural character of the village. So did the houses' items of 'decoration' and 'lighting', which were limited to chimney cloth, curtains, lanterns, and iron chandeliers. Gilded mirrors, paintings, and decorated furniture were not found among the auctioned products. Books only appeared in three lots, at the end of the century. ${ }^{24}$ The most expensive products were 'bedding' and 'jewellery'. These figured frequently in price ranges above 5 and 10 guilders (in 1750, for instance, a gold ring fetched 5 guilders and a valuable watch, 14 guilders). Beds and sheets symbolized luxury, quality, and wealth for an early modern village community: tearing bed linen to pieces was taken very seriously in marriage disputes and beds were often given as wedding dowries. ${ }^{25}$ Some items were more valuable because the raw materials from which they were made were expensive. These included items like a 'woollen' shirt, a 'cupper' kettle, and a 'feather' bed worth a staggering 50 guilders around 1750 . In general, however, most products, and especially kitchen utensils, were found in the lowest price ranges (see Figures 4-7). In the 1750 s, almost two-thirds of the products that were sold for 0.25 guilders 


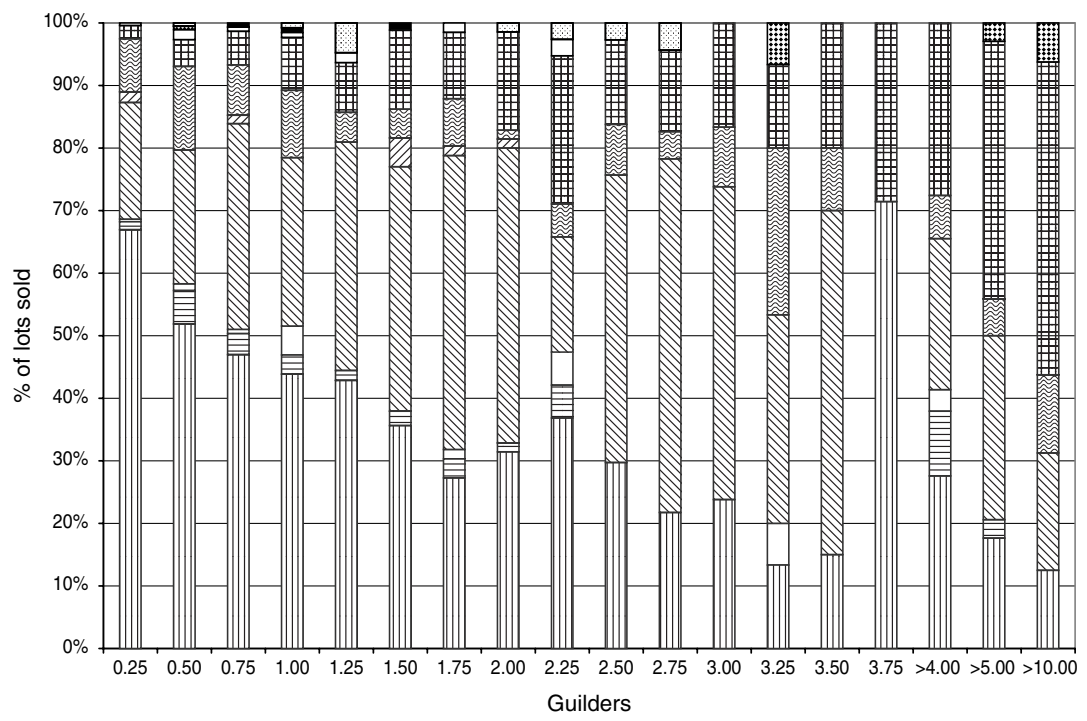

$\square$ Kitchen utensils $\boxminus$ Kitchen linen $\square$ Cleaning and sewing things $₫$ Clothing $\oslash$ Shoes 类 Furniture 田 Bedding $\square$ Lighting Decorations 四 Jewellery $\square$ Others

FIGURE 5. Second-hand goods sold at the vendities in Erembodegem, 1750-1759, by price and category (\%). (Source: See Figure 1.)

or less were kitchen utensils. Clothing, however, was found more often in the higher price ranges: of all the products sold for 3.75 guilders in the 1750 s over 70 per cent, were some type of clothing. Auction values at the end of the century show a similar pattern, with clothing generally being auctioned at a higher price than kitchen utensils.

All the product categories were found in a wide variety of price ranges, depending on the individual items offered and the varying conditions from sale to sale. Indeed, the prices received from the sale of second-hand products reflected the market value of the auctioned goods. It is possible that similar products fetched different retail prices when bought from sellers of old-clothes, rag-and-bone men or other commercial resellers, for whom our information is scanty. In Erembodegem goods were sold to the highest bidder by strictly prescribed procedures. ${ }^{26}$ Products could be viewed beforehand, but purchases had to be made on the spot, with little time for doubt or second thoughts. This factor, still current today, could influence the value of transactions, depending upon public whim or the experience of the auctioneer. For example, the commercial attitude of the auctioneer (the stockslager) could inflate or deflate transaction prices. ${ }^{27}$ Indeed, his ability to sense the atmosphere and to play on the emotions of 


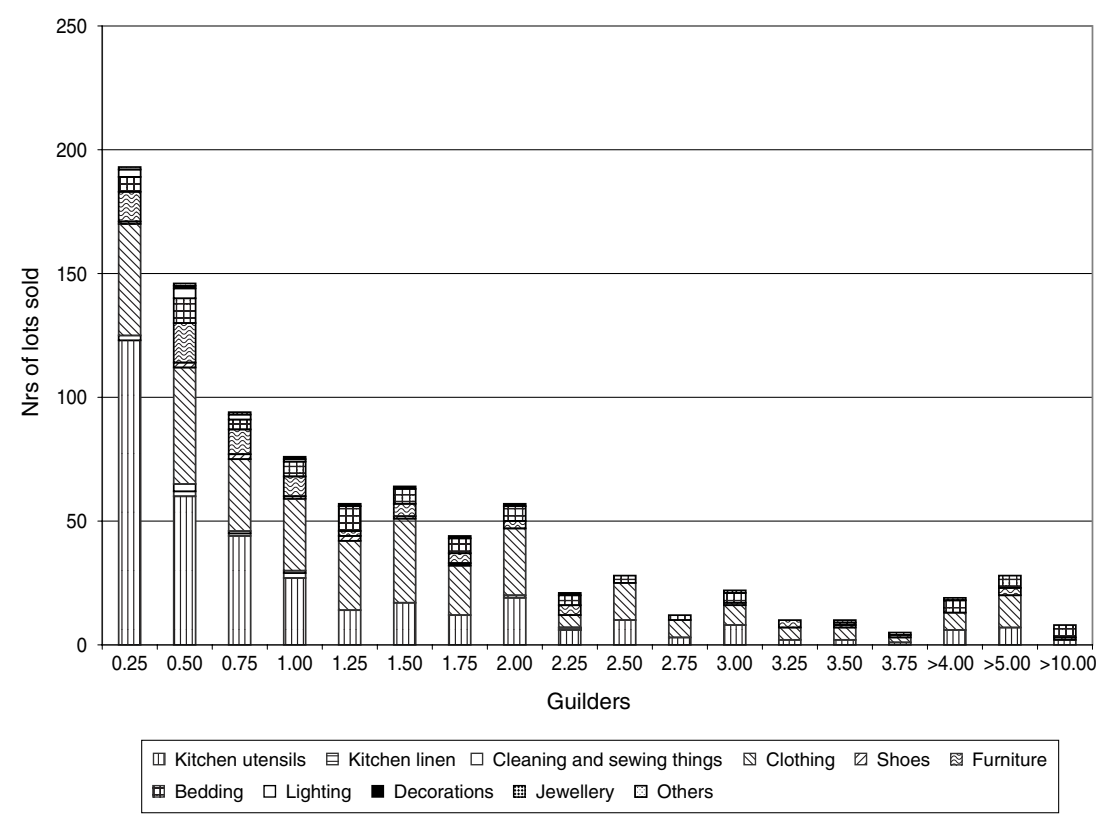

FIGURE 6. Second-hand goods sold at the vendities in Erembodegem, 1785-1794, by price and category. (Source: See Figure 1.)

frenzied buyers was instrumental in increasing the hammer price. ${ }^{28}$ Contemporary accounts even relate that auctioneers would try to bid up the price of items unjustly, presumably because they took a fixed percentage of the hammer price. ${ }^{29}$

The overall picture suggests a rather 'egalitarian' commercial circuit that consisted primarily of very cheap products. Moreover, the median value of auction-sale prices for all categories of goods remained stable (for 'decorations' and 'furniture') and even declined by the end of the eighteenth century (for all other categories), bringing most second-hand lots within the price-range of a widening social group. This brings us to the question of the statistical composition of sellers and buyers at the auctions in Erembodegem.

I I

The 41 households under study, each selling the possessions of a deceased relative, were relatively evenly spread among all the socio-economic groups in Erembodgem, and were thus generally representative of the 


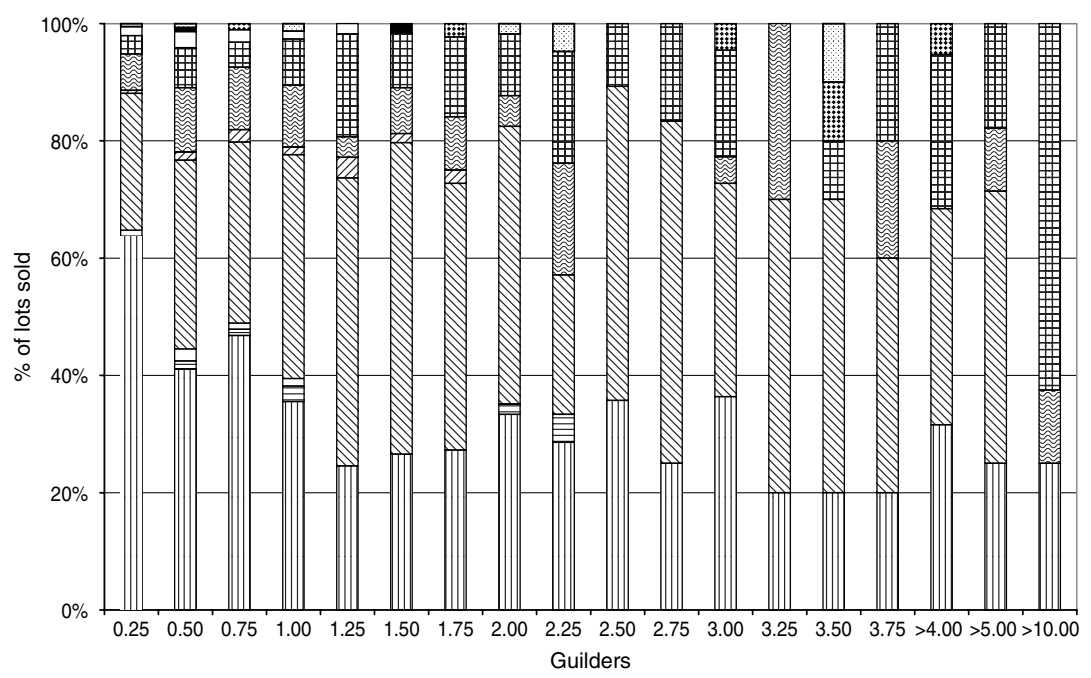
$\square$ Kitchen utensils $\boxminus$ Kitchen linen $\square$ Cleaning and sewing things $\nabla$ Clothing $\square$ Shoes 图 Furniture
$\boxplus$ Bedding $\square$ Lighting Decorations $\quad$ Jewellery $\quad$ O Others

FIGURE 7. Second-hand goods sold at the vendities in Erembodegem, 1785-1794, by price and category (\%). (Source: See Figure 1.)

village as a whole (see Table 1). ${ }^{30}$ The types and levels of economic activity of these households in our selected periods (in the 1750s and around 1790) did not differ significantly from those of the larger local economy. ${ }^{31}$ One major observable difference between the two periods, however, is an apparent decline of auctioning in the latter half of the eighteenth century: in absolute and in relative terms almost all the socio-economic categories of sellers declined in numbers, except household category II. Around 1750, only 28 per cent of sellers came from households situated in the lowermiddle (II) or lower (I) segments of society; around 1790 this had risen to almost 44 per cent. Moreover, the decline in both the total volume of transactions and the overall value mentioned earlier likely resulted from a general decline in standards of living. As a result poorer households, no doubt owning fewer and cheaper belongings, were over-represented. Families belonging to the higher socio-economic statuses (III and IV) usually had more varied goods and a greater quantity of them on offer in both our sample periods (see Figures 8 and 9). Apparently, even the wealthiest families from Erembodegem were prepared to re-sell their possessions at auction.

Explaining these changes in the socio-economic background of the sellers in Erembodegem is a potentially dangerous exercise, because the 
T A B LE 1

Socio-economic status of sellers at the vendities in Erembodegem, 1750-1759 and 1785-1794

\begin{tabular}{lrrrrr}
\hline \hline \multirow{2}{*}{$\begin{array}{l}\text { Household category } \\
\text { of sellers }\end{array}$} & \multicolumn{2}{c}{$1750-1759$} & & \multicolumn{2}{c}{$1785-1794$} \\
\cline { 2 - 3 } \cline { 5 - 6 } & $N$ & $\%$ & & $N$ & $\%$ \\
\hline I & 4 & 16 & & 2 & 12.5 \\
II & 3 & 12 & & 5 & 31.25 \\
III & 9 & 36 & & 25 \\
IV & 8 & 32 & & 25 \\
Unknown & 1 & 4 & & 1 & 6.25 \\
Total & 25 & 100 & & 16 & 100 \\
\hline \hline
\end{tabular}

${ }^{a}$ For definitions see note 30 .

Source: Unpublished database based on Municipal Archives Alost, Oud Archief Erembodegem, staten van goed, nrs 1369-78 and 1404-13, and settingen, nrs 251 en 255.

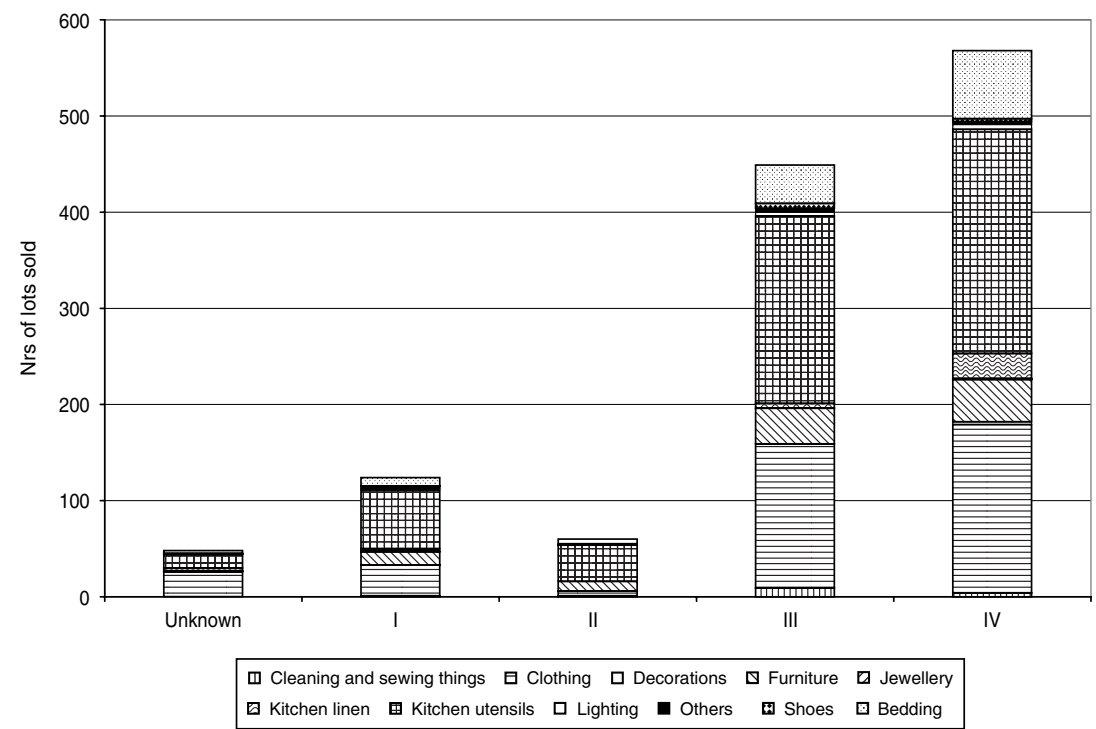

FIGURE 8. Second-hand goods sold at the vendities in Erembodegem, 1750-1759, by socioeconomic status of seller. (Source: See Figure 1.)

number of vendities was, in general, rather small and chronologically unevenly distributed. It remains difficult to gauge whether these changes reflect actual changes in second-hand auctioning or simply alterations in 


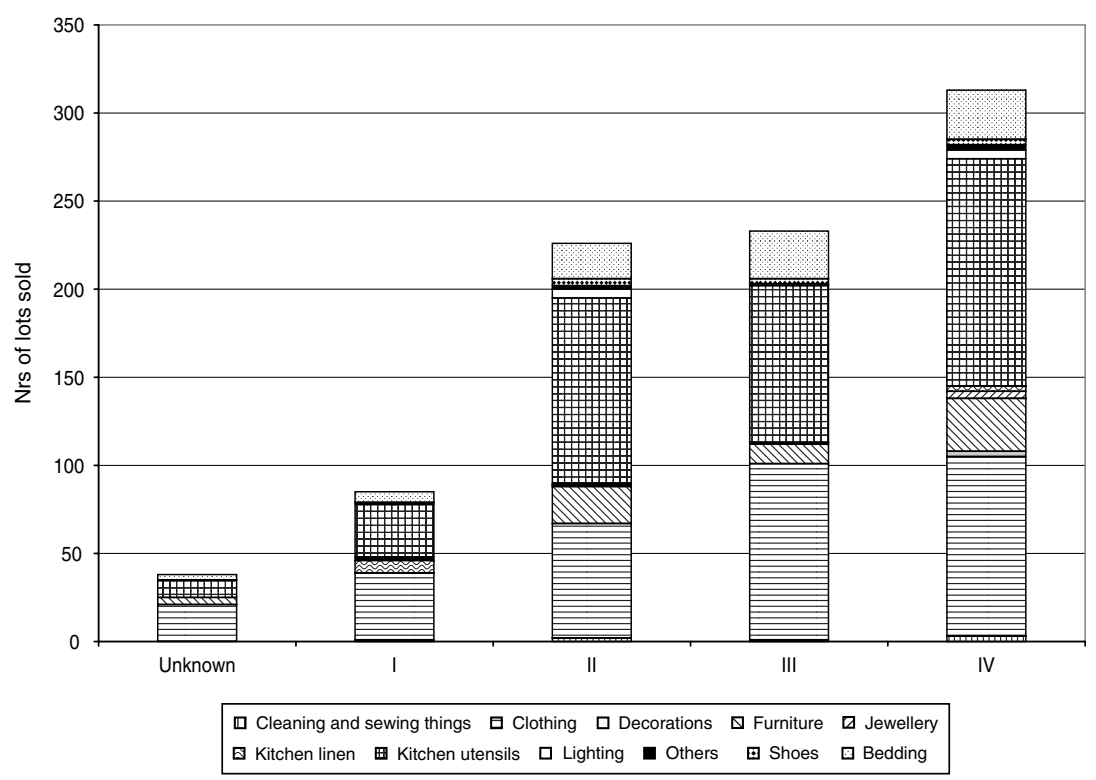

Figure 9. Second-hand goods sold at the vendities in Erembodegem, 1785-1794, by socio-economic status of seller. (Source: See Figure 1.)

the bequeathing of personal property. In any case, we have found no evidence that people tended to arrange the way they left their property differently at the end of the eighteenth century than in the middle.

Examining the buyers at the auctions in Erembodegem is also a complex affair. Indeed, matching all buyers to their geographical and socioeconomic backgrounds is a complex undertaking. A comparison of all the buyers' names with the contemporary tax lists (the settingen) and with our demographic source (the status animarum) around 1750 yielded positive identification of 336 Erembodegem households (see Table 2) ${ }^{32}$ Thus, of a total of about 370 households in Erembodegem at that time (or 378, depending on the sources used), a staggering 91 per cent of all households in the village participated in the auctions, 86 per cent of all buyers at the vendities ${ }^{33}$ Similar figures were found for the end of the eighteenth century but, again, the decline in auction activity is apparent. Only 49 per cent of the households in Erembodegem continued to be active buyers at the auctions around 1790, although these accounted for 89 per cent of all buyers. ${ }^{34}$ To keep transport and storage costs in check, the auctions of household effects normally took place on the premises of the late owner ${ }^{35}$ This also occurred in Erembodegem and explains the strong local 
TABLE 2

Geographical origins of buyers at the vendities in Erembodegem, $1750-1759$ and $1785-1794$

\begin{tabular}{lccccc}
\hline \hline & \multicolumn{2}{c}{$1750-1759$} & & \multicolumn{2}{c}{$1785-1794$} \\
\cline { 2 - 3 } \cline { 5 - 6 } Place of origin & $\begin{array}{c}\text { \% of transactions } \\
(N)\end{array}$ & $\begin{array}{c}\% \text { of buyers } \\
(N)\end{array}$ & & $\begin{array}{c}\text { \% of transactions } \\
(N)\end{array}$ & $\begin{array}{c}\text { \% of buyers } \\
(N)\end{array}$ \\
\hline Alost & $9(111)$ & $3(12)$ & & $8(73)$ & $2(6)$ \\
Erembodegem & $84(1045)$ & $86(336)$ & & $86(766)$ & $89(227)$ \\
Other villages & $7(93)$ & $11(44)$ & & $6(56)$ & $9(23)$ \\
Total $(\%)$ & 100 & 100 & & 100 & 100 \\
Total $(\mathrm{N})$ & 1,249 & 392 & & 895 & 256 \\
\hline \hline
\end{tabular}

Source: As in Table 1.

TABLE 3

Socio-economic status of buyers at the vendities in Erembodegem, $1750-1759$ and $1785-1794$

\begin{tabular}{lccccc}
\hline \hline & \multicolumn{2}{c}{$1750-1759$} & & \multicolumn{2}{c}{$1785-1794$} \\
\cline { 2 - 3 } \cline { 5 - 6 } $\begin{array}{l}\text { Household } \\
\text { category } \\
\text { of buyer }^{a}\end{array}$ & $\begin{array}{c}\text { \% of transactions } \\
(N)\end{array}$ & $\begin{array}{c}\text { \% of buyers } \\
(N)\end{array}$ & & $\begin{array}{c}\text { \% of transactions } \\
(N)\end{array}$ & $\begin{array}{c}\text { \% of buyers } \\
(N)\end{array}$ \\
\hline I & $10(104)$ & $8(28)$ & & $13(101)$ & $12(27)$ \\
II & $8(81)$ & $7(24)$ & & $19(148)$ & $11(26)$ \\
III & $16(162)$ & $12(39)$ & & $6(48)$ & $6(13)$ \\
IV & $12(129)$ & $11(37)$ & & $17(129)$ & $13(29)$ \\
Unknown & $54(569)$ & $62(208)$ & & $45(340)$ & $58(132)$ \\
Total $(\%)$ & 100 & 100 & & 100 & 100 \\
Total $(\mathrm{N})$ & 1,045 & 336 & & 766 & 227 \\
\hline \hline
\end{tabular}

${ }^{a}$ For definitions see note 30 .

Source: As in Table 1.

component among the buyers. Still, these statistics reveal an obvious decline in the number of buyers or, more precisely, in the number of buyers from Erembodegem and nearby hamlets and villages.

Tying buyers of Erembodegem to their corresponding socio-economic categories is difficult, and yields a large and probably distorting category of 'unknown' persons (see Table 3). Nevertheless, our data seem to suggest that those from all social backgrounds in Erembodegem, from poor to wealthy households alike, participated in the auctions of second-hand items. Motivations for doing so, however, were complex and probably 


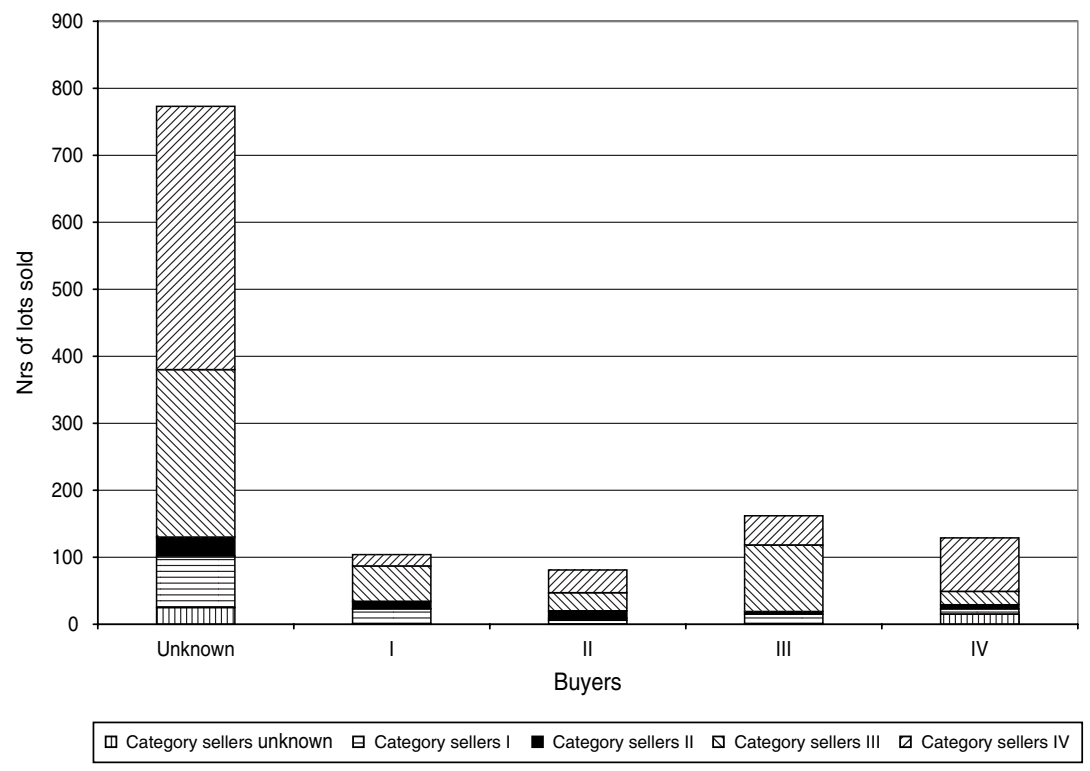

FIGURE 10. Buyers and sellers of second-hand goods sold at the vendities in Erembodegem, $1750-1759$, by socio-economic category of household. (Source: See Figure 1.)

differed. One way of testing these assumptions is to examine the social circulation of auctioned objects and link this to what might have been the specific consumer rationale for buying second-hand goods. Indeed, our two venditie samples show how products moved both between homes of the same social status and between different socio-economic categories (see Figures 10-13). Buyers from the lower layers of society (household categories I and II) especially frequented sales of higher-placed households (more evident in the sample from the 1750s). But the reverse could also be true: people from the higher echelons bought certain objects from poor or middling families or remained within their own socio-economic category in their purchases.

How can these buying practices be explained? According to Gregson and Crewe, at least three motivations for acquiring second-hand items were in play, depending on the product offered and the individual interests of the buyer. ${ }^{36}$ The first was budget constraints, as people bought older goods out of financial necessity. Second-hand consumption thus was practised by the lower tiers of society. Products in the category 'clothing' were especially sought after for just that reason: buying garments at auction afforded the needy access to more and better qualities of textiles than they could normally afford. Jon Stobart has noted how an increase in 


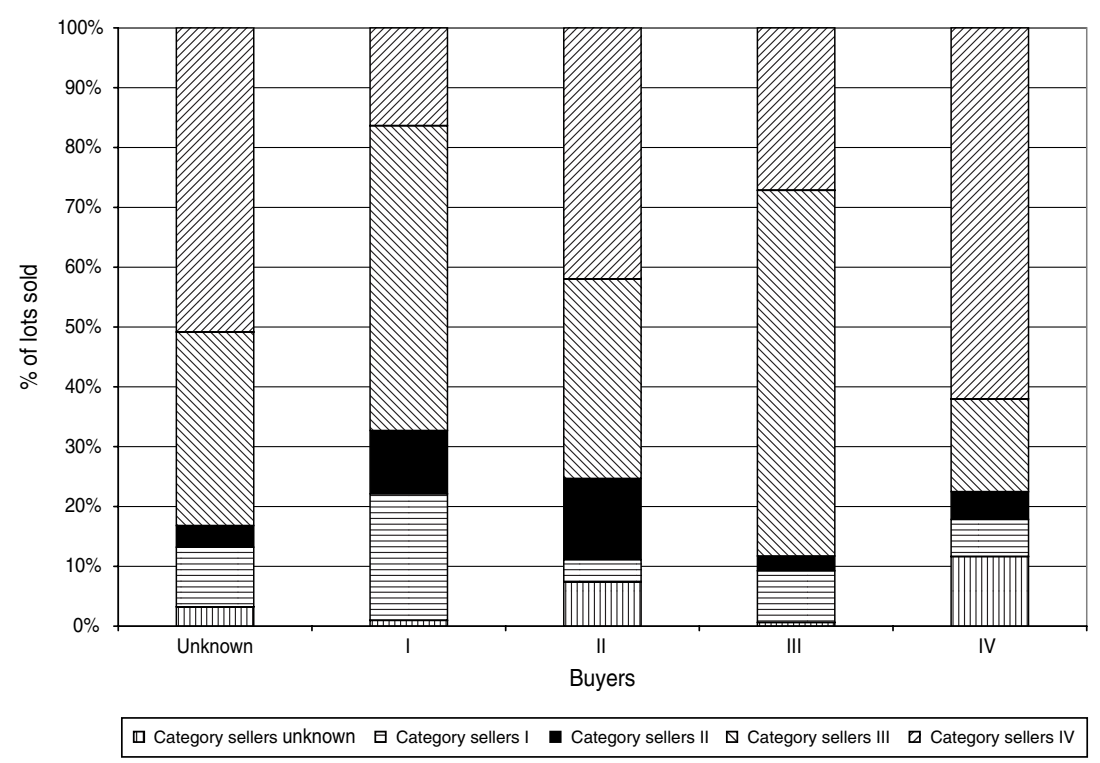

FIGURE 11. Buyers and sellers of second-hand goods sold at the vendities in Erembodegem, 1750-1759, by socio-economic category of household (\%). (Source: See Figure 1.)

dealings in old clothes follows the marginalization of a workforce. ${ }^{37}$ Beverly Lemire has forcefully argued that the demand for clothing in eighteenth-century England was 'two-tiered ${ }^{38}$ An upper tier of middling layers of society and wealthy consumers, she argued, increasingly bought new clothing and textiles. Complementing this world of leisurely shopping and polite behaviour, a second and lower tier with lesser wealth purchased cast-offs and démodé products, goods that were abandoned by the wealthier in the craze for novelties and fashion. Economic well-being in the eighteenth century was reflected in the fact that second-hand clothing became a sign of poverty, something unclean and unworthy of polite and civilized society.

As for clothing in rural Erembodegem, the number of transactions had decreased by the end of the eighteenth century, as did the median value of auction prices (from 1.5 guilders to 1.25 guilders per transaction). The number of clothing-buyers dropped in the period studied, from 195 in the 1750 s to 139 around $1790 .^{39}$

In both periods, buyers of clothing came predominantly from the lower and lower-middle tiers of the agrarian community: 57 per cent of the identified buyers came from socio-economic categories I and II in the 1750 s, and 67 per cent by 1790. Interestingly, buyers from these lower 


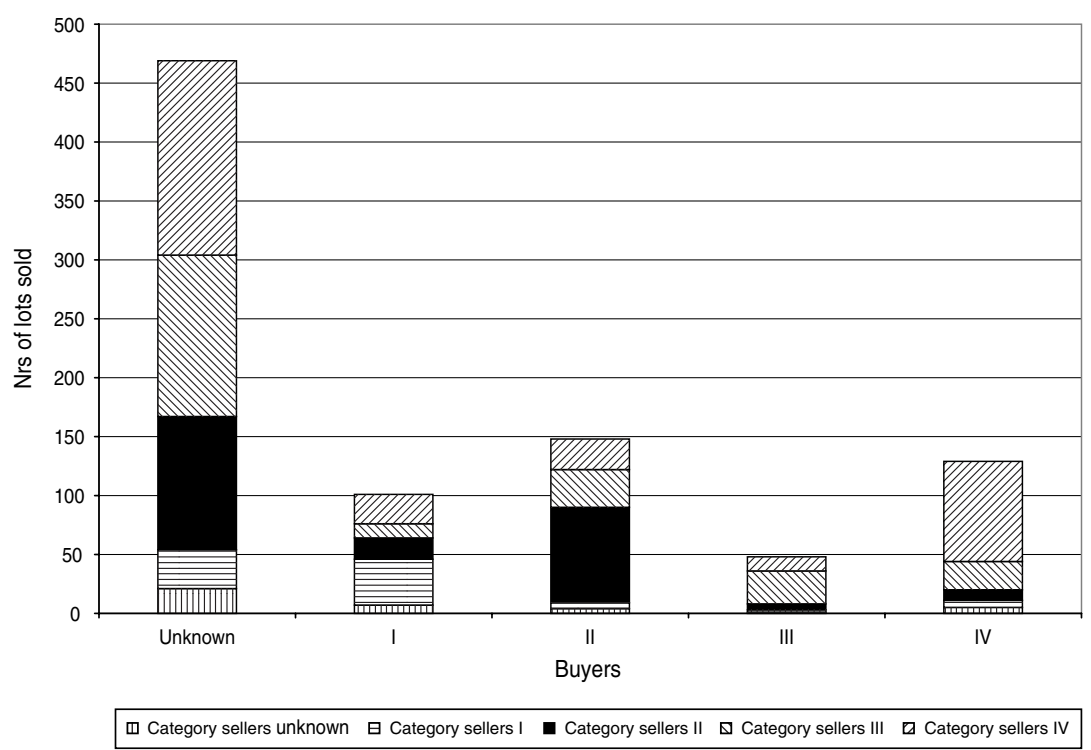

FIGURE 12. Buyers and sellers of second-hand goods sold at the vendities in Erembodegem, 1785-1794, by socio-economic category of household. (Source: See Figure 1.)

socio-economic categories almost always bought their clothing from their betters (in categories III and IV especially), and this pattern suggests a second motivation for buying second-hand.

Indeed, purchasing older belongings can be linked to notions of social identity and status. The quantity and relative costliness of second-hand goods is important, as is their capacity to mark differences in, or emulate, higher socio-economic status. Late-eighteenth-century England, for example, saw the arrival of the bourgeois macaroni, the aspirant gentlemen who demanded second-hand finery. ${ }^{40}$ In the southern Netherlands, the craze for French fashions in the eighteenth century led to growing social commentary about housekeepers imitating their masters by wearing outfits that were hand-me-downs. Humble daughters pretended to be noble ladies, wearing a variety of easily accessible status luxuries (fans, ribbons, handkerchiefs, and so on). ${ }^{41}$ Expensive, novel items of high status, such as snuffboxes and watches, could be obtained thanks to second-hand purchase. ${ }^{42}$ At Erembodegem's humble countryside vendities, few auction lots captured this kind of difference in style and taste. But perhaps an individual transactions concerning a teakettle or a chimney cloth around 1750 , or a watch or fancy curtains around 1790 , were made with such intent. Auction lots including clothing, however, could also circulate 


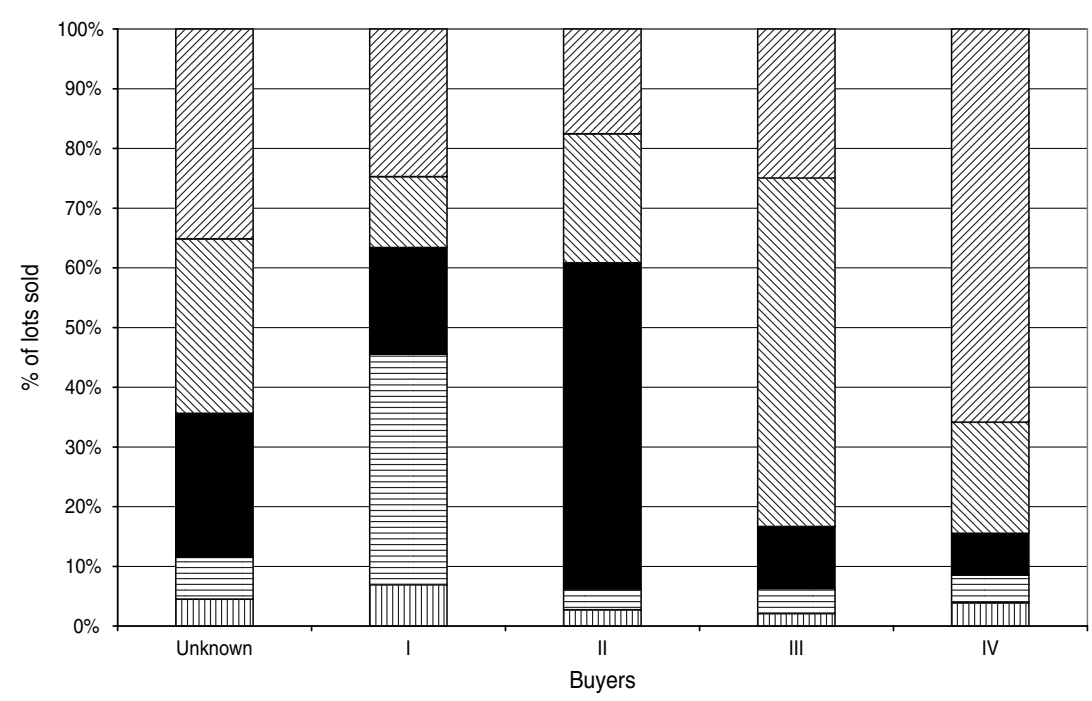

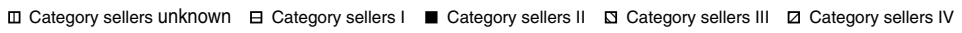

FIGURE 13. Buyers and sellers of second-hand goods sold at the vendities in Erembodegem, 1785-1794, by socio-economic category of household (\%). (Source: See Figure 1.)

upwards, indicating that, in rural Flanders at least, economic and social polarization around these products was not yet fixed as Lemire noted for England. Clearly, not just economic or social rationales were at work at the vendities in Erembodegem, and this helps to explain the attendance of buyers from higher-status social categories at sales in the homes of lower families.

Auction lots in Erembodegem largely featured goods with high use value, such as kitchenware, bedding, linens, and cleaning and sewing things. This point brings us to the third major reason for buying secondhand, one that links the very poor to the very rich. Consuming used belongings is about 'capturing value', that is, acquiring higher-value or better-quality goods for less money. ${ }^{43}$ The lower and the higher tiers of society were interested in buying high-quality furniture (tables or chairs), for example, at prices below the market ones for newly made items. This was 'clever consumption' motivated by thrift or a sense of getting a 'bargain'. Jacques Savary, a French writer of a popular commercial manual, urged his early-eighteenth-century contemporaries to buy at auctions. By so doing, Savary claimed, they would quickly increase their consumption budgets by 10 per cent, "plus de dix pour cent de bon marché'. ${ }^{44}$ Buying older products of good quality, especially in an 
eighteenth-century market with changing standards of product durability, was a 'clever investment'. These goods were more easily repaired, and could eventually be resold, or pawned during times of hardship. Moreover, as opposed to clothing, goods with high use value were relatively immune to sudden fashion changes. ${ }^{45}$

Of the buyers of the most popular product categories that can be identified ('kitchen utensils', 'furniture', and 'bedding'), most were in socio-economic category III. In general, and most particularly for the years around 1790, these goods were bought at sales of goods from people of the same economic class: many people in Erembodegem apparently bought and reused goods that most frequently had been used by members of their corresponding social station.

Of course, other intentions drove consumers to the auctions in Erembodegem, shedding light on their broad social appeal. Today, reuse of older products is sometimes inspired by 'ecology', a reaction to the modern-day abundance of consumer goods. In the latter half of the eighteenth century, particularly in the countryside, goods could be scarce or only sporadically available, thus leading to a pragmatic, opportunistic approach from all strata of society. ${ }^{46}$ Indeed, such attitudes can explain why many goods circulated both downwards and upwards. Arguably, auctions of household effects were sought because of the relative choice of products offered (depending of course on the wealth of the late owner).

Professional and commercial interests could also be in play when the buyer was a dealer. The data in Table 2 illustrate that buyers from Alost represented a tiny minority of all bidders, yet they bought almost 10 per cent of all the auction lots in both periods. Thus, durable consumer goods not only passed from the city to the countryside but certain urbandwellers also bought large quantities of products in the countryside. ${ }^{47}$ The reasons for doing so were almost certainly commercial. In our sample from around 1750, two buyers from Alost, Jan Baptist Mercola and Jan De Clippel, appear to have been professional 'second-hand dealers'. ${ }^{48}$ Their investment in the venditities at Erembodegem amounted to 3 per cent of the total value of all auctioned goods. ${ }^{49}$ In doing so, they bought many different products without focusing on particular types of goods. Their products included a flatiron, shirts, skirts, napkins, underwear, sheets, and even pewter kitchenware and a feather bed. They also attended more than one auction: Mercola was active at three vendities, De Clippel at eight. Moreover, in Alost both dealers were inn-keepers, catering to the middle layers of society. Mercola's inn was in the Hoogstraat, and Jan De Clippel operated a tavern called 'De Roose' in the Lange Ridderstraat. ${ }^{50}$ Their 'multiple job-holding' was probably not coincidental: previous research has indicated how inns and taverns were instrumental in a myriad 
T A B LE 4

Members of the nuclear family of the deceased bidding at the vendities in Erembodegem, 1750-1759 and 1785-1794 (\%)

\begin{tabular}{lccccc}
\hline \hline & \multicolumn{2}{c}{$1750-1759$} & & \multicolumn{2}{c}{$1785-1794$} \\
\cline { 2 - 3 } \cline { 5 - 6 } & $\begin{array}{c}\text { \% of all } \\
\text { transactions }^{a}(N)\end{array}$ & $\begin{array}{c}\text { \% of all } \\
\text { buyers }(N)\end{array}$ & & $\begin{array}{c}\text { \% of all } \\
\text { transactions }(N)\end{array}$ & $\begin{array}{c}\text { \% of all } \\
\text { buyers }(N)\end{array}$ \\
\hline Spouse & $8(104)$ & $3(10)$ & & $12(106)$ & $3(8)$ \\
Daughter & $11(132)$ & $5(20)$ & & $1(13)$ & $1(3)$ \\
Son & $16(199)$ & $11(42)$ & & $17(148)$ & $8(20)$ \\
Son-in-law & $6(76)$ & $4(15)$ & & $5(41)$ & $5(12)$ \\
Total nuclear family & $41(511)$ & $22(87)$ & & $35(308)$ & $17(43)$ \\
\hline \hline
\end{tabular}

a For 'all transactions' and 'all buyers' see Table 2.

Source: As in Table 1.

of semi-legal and illicit dealings. Innkeepers acted as 'fences' for stolen goods, and inns were used as auction sites or places where buyers and sellers of all social orders could meet in relative privacy. Needless to say, such practices regularly evoked the wrath of official guildsmen. ${ }^{51}$

Around 1790, attending auctions out of commercial motivation - the re-selling of second-hand products - remained in vogue. Of the six buyers from Alost in our sample, at least two were obvious commercial middlemen, active in the guild of retailers (the ambacht van de veysteriers). ${ }^{52} \mathrm{It}$ is no longer possible to determine whether these two citizens, Bernardus Cremer and Jan Noë, were active as regular shopkeepers or itinerant tradesmen. ${ }^{53}$ We know, however, the specific products they bought at the vendities in Erembodegem. Cremer purchased two pewter dishes for 2 guilders, but, most importantly, he invested 46 guilders in auction lots including clothing and textiles. Noë also had a special interest in shirts and other clothes. Acknowledging their mutual social standing - situated again in the middling layers of society - it becomes plausible to identify these persons as urban clothes-sellers, dealing in a broad range of apparel. Their focus on clothing was perhaps related to changing social conditions in Alost, a product of early industrialization within the city walls. ${ }^{54}$

Buyers from the nearby city of Alost, however, were a minority compared with the local attendees at the auctions. Among the buyers from Erembodegem, the deceased's immediate family (children and spouse) were especially prominent auction bidders (see Table 4). Around 1750, the immediate family was responsible for 41 per cent of all transactions and constituted 22 per cent of all buyers. At the end of the eighteenth century, 
these percentages had declined to 35 per cent and 17 per cent respectively, a tendency that corresponded to the previously mentioned drop in auction activity.

The importance of heirs participating in auctions of a deceased relative depended upon the customary law regarding the inheritance of moveable property in this part of Flanders. These laws introduce another tacit consumer motivation, albeit probably the most elusive to comprehend. Re-buying possessions from relatives, or even from acquaintances, touches the emotional level, which defies economic, social, practical, and professional motives. It involves close knowledge of the prior use, value, and meaning of the auctioned goods.$^{55}$ No longer are only the financial value, appearance, or quality of the product at stake; buying second-hand products centres, in part, on the true 'biography of things', which for whatever reason remained a meaningful motivation for purchase. The source of a second-hand item is a prior consumer rather than its original producer, and Grant McCracken has acknowledged how the consumption of older products usually requires 'divestment rituals' such as cleansing, purification, and personalization to reduce the traces or marks of previous owners. Sometimes, however, these older imprints are sought after and left untouched, indicating a special veneer or 'patina' that embodies precisely the crucial meaning or value of the product for the purchaser. $^{56}$

Illustrative in this respect seems to be the auctioning of wedding beds, which were a costly but crucial piece of furniture for rich and poor alike. Beds, to be sure, were central to a marriage arrangement and symbolized, together with the hearth, domesticity. ${ }^{57}$ In Erembodegem a total of 31 'beds' (bedden) of various sorts were auctioned around 1750: 24 were bought by direct heirs, on 7 of these occasions by the deceased's partner, on 15 by a child (son or daughter), and twice by a son-in-law. A similar pattern could be traced for the end of the eighteenth century: of the 18 auctioned beds, surviving partners bought 6 and children 8 . In both periods, children were the highest bidders when both the late owner (father or mother) and his/her spouse were dead. This practice illustrates the crucial but so far largely unnoticed importance of these sentimental reuse practices.

The reuse of older products thus emerges as a widespread and sensible consumer strategy. Second-hand consumption, practised by different layers of society, albeit for different reasons and varying products, can be interpreted as a fundamental alternative to the acquisition of new goods. 
In this article, we have looked at second-hand consumption only through the auctioning of possessions of deceased owners. However, many more circumstances that led to reuse existed in early modern times. These include goods bestowed upon heirs, given to friends, stolen, and bought from those commercial dealers scavenging the streets and countryside. ${ }^{58}$ Second-hand consumption was truly a way of life or, as Donald Woodward noted in a pioneering work: 'Few goods were lightly abandoned; fewer still were left to rot by the roadside. ${ }^{59}$ This mentality did not change in a fortnight, although things were clearly changing during the eighteenth century. It is sometimes assumed that the reuse of older objects gradually diminished in this period as a result of increased productsubstitution. Swift fashion cycles, for instance, led Adam Smith to conclude that English furniture and clothing around 1759 were no longer made 'of very durable materials' ${ }^{60}$ Changes in production techniques and the use of less costly basic materials (like cotton) furthered this process. ${ }^{61}$ The eighteenth-century 'world of goods' fell easier out of fashion and reuse became more difficult because of the lighter, more breakable, and less durable nature of products. ${ }^{62}$ These changes in the material culture are believed to have depressed the relative and total value of household goods in general, and of commercial dealings in secondhand products in particular. ${ }^{63}$ Daniel Roche, on the other hand, has noted how parallel consumer changes could adversely affect the overall reuse pattern in the short term: more consumption in general and a shortened life-cycle of goods in particular led to an increased number of cast-offs. ${ }^{64}$

Although similar changes were occurring in the southern Netherlands, it remains problematic to confirm these hypotheses regarding the secondhand market on the basis of our auction material from Erembodegem. The lack of elaborate product-descriptions in the sources renders it difficult to detect actual changes on the demand side. Our sources cannot reveal, for instance, if the drop in transactions and in the overall value of auctioned clothing lots around 1790 was the result of shirts and skirts being of lesser product quality. Devaluation of products, then, might have caused the decline in the overall prices received at auctions. With fashions changing ever faster, and new, less durable goods being introduced more rapidly, investing money in older products was less practical. Conversely, with the general price level of second-hand goods dropping for similar reasons, selling valuable property became less economically rational. Only auction lots including kitchen utensils seem to provide sufficient detail to shed some light on the process. These goods remained popular and sought-after items, although the number and median value of all transactions plummeted in the half-century 
TABLE 5

Buyers of earthenware and pewter at the vendities in Erembodegem, $1750-1759$ and $1785-1794$

\begin{tabular}{|c|c|c|c|c|}
\hline & \multicolumn{2}{|c|}{$1750-1759$} & \multicolumn{2}{|c|}{$1785-1794$} \\
\hline & $\begin{array}{c}\% \text { of } \\
\text { transactions } \\
(N)\end{array}$ & $\begin{array}{c}\% \text { of } \\
\text { buyers } \\
(N)\end{array}$ & $\begin{array}{c}\% \text { of } \\
\text { transactions } \\
(N)\end{array}$ & $\begin{array}{c}\% \text { of } \\
\text { buyers } \\
(N)\end{array}$ \\
\hline \multicolumn{5}{|l|}{ Earthenware } \\
\hline From Alost & $0(0)$ & $0(0)$ & $0(0)$ & $0(0)$ \\
\hline Erembodegem (no neighbour) & $40(42)$ & $45(33)$ & $50(16)$ & $59(13)$ \\
\hline Neighbour (no family) & $10(10)$ & $13(9)$ & $0(0)$ & $0(0)$ \\
\hline Nuclear family member & $50(51)$ & $42(30)$ & $50(16)$ & $41(9)$ \\
\hline Total $(\%)$ & 100 & 100 & 100 & 100 \\
\hline Total (N) & 103 & 72 & 32 & 22 \\
\hline \multicolumn{5}{|l|}{ Pewter } \\
\hline From Alost & $27(10)$ & $19(5)$ & $5(1)$ & $10(1)$ \\
\hline Erembodegem (no neighbour) & $32(12)$ & $29(8)$ & $40(8)$ & $40(4)$ \\
\hline Neighbour (no family) & $14(5)$ & $19(5)$ & $5(1)$ & $10(1)$ \\
\hline Nuclear family member & $27(10)$ & $33(9)$ & $50(10)$ & $40(4)$ \\
\hline Total $(\%)$ & 100 & 100 & 100 & 100 \\
\hline Total (N) & 37 & 27 & 20 & 10 \\
\hline
\end{tabular}

Source: As in Table 1.

under consideration. Unlike clothing, kitchen utensils were sometimes specified according to their composition, thus allowing better insight into long-term changes and the popularity of certain raw materials (see Table 5).

As our ongoing research has confirmed, earthenware was gradually losing importance for rural households ${ }^{65}$ At the Erembodegem vendities, older earthenware was clearly being reused less and bought by fewer people as the eighteenth century progressed. Around 1790 only direct relatives of the deceased bought earthenware second-hand, perhaps for sentimental reasons. Clearly, earthenware had become a 'throwaway product' for most people: it was bought new and, because of its less durable quality, was valued and reused less. Pewter underwent a similar evolution, albeit one that was somewhat different and less obvious. ${ }^{66}$ At the end of the eighteenth century, the neighbours and commercial middlemen from Alost were still buying pewter, but by around 1750 the buyers from the nearby city had already lost interest in earthenware. The importance of the immediate family in buying it second-hand was 
rising, but, unlike for earthenware, almost all buyers of pewter were from the upper tiers of society. Thus, the relatives of these well-off households regarded pewter as too valuable for reuse outside the immediate family.

Concluding this empirically structured case study is no easy matter. Further research is needed to assess the impact of the consumption and circulation of reused goods in eighteenth-century society. Nevertheless, this modest exercise shows that contemporary accounts of consumption must recognize these alternative 'consumer flows'. Indeed, studying the motives underpinning second-hand purchases offers insights into the current debate on consumption patterns.

Firstly, the attention devoted to second-hand clothing in literature must be amplified by further study into other consumer goods. In Erembodegem, kitchen utensils, furniture, and 'bedding' were frequently sold along with clothing, requiring a more general analysis of reuse habits than has been undertaken so far. Secondly, motivations for discarding and buying older belongings could, and did, differ from product to product, and involved a wider range of actors than is sometimes thought. ${ }^{67}$ Besides the importance of the objects purchased, there must also be acknowledgement of the specific social and geographical background of the buyers and sellers of older goods. In Erembodegem, it seems safe to assume that local residents who participated in the auctions in this period came from many social strata. Auctioning second-hand products remained a way of life for almost every household in the eighteenth century, although auctioning was probably diminishing as the century progressed. Thirdly, reuse habits, or even a 'reuse mentality' has changed significantly in the past two to three hundred years. Of course, changes on the demand side also influenced this. The infamous "birth of a consumer society' in the eighteenth century slowly affected how 'old' and 'second-hand' were perceived. ${ }^{68}$ At one end of the spectrum, 'neophiliac' and 'throwaway' behaviour pushed second-hand buyers to the fringes; buying or reusing older belongings became socially marginalized and an indicator of lower economic and social status. Yet emerging romantic sentiments (among other things) spurred the rise of a specialized 'second-hand industry' that pandered to collectioneurs, buyers fond of the products of the past. ${ }^{69}$ Based on our samples from the years around 1750 and 1790, it remains unclear to what extent the second-hand market of Erembodegem was already marked by these 'transitional' changes. The example of the auction lots containing earthenware, however, 
suggests that even rural Flanders was not isolated from broader changes in society.

Most importantly, this article urges reconsideration of rash conclusions about poverty-stricken peasants supposedly devoid of rational economic strategies. Confronted with cyclical agrarian setbacks, reusing older products remained an important consumer strategy. Second-hand consumption, although widely neglected by historians (who generally stress the marginalization of the Flemish countryside in the eighteenth century), in fact arguably 'enlarged' the world of possessions that farmers owned. ${ }^{70}$ In Erembodegem auctions provided an 'egalitarian circuit', with a wealth of cheap goods that were sold more often and at better prices than first-hand goods. There is much more to be learned in studying consumer demand for these types of goods.

\section{APPENDIX:A NOTE ON THE SOURCES}

Apart from its importance in proto-industrial historiography, the choice of Erembodgem as our object of study was based partly on practical reasons. Unlike many villages and cities in present-day Belgium, the archives of Erembodegem contain inventories with matching vendities documents. ${ }^{71}$ This archival record makes Erembodegem an interesting case for investigating reuse habits in the past. Household information mentioned in probate inventories could be combined with stati animari: lists containing all the household members in a certain Catholic parish. These data from the mid-eighteenth century facilitated a demographic survey of the samples, to which was added a detailed study of household reconstruction. ${ }^{72}$ Using the names of householders, all but one of the 41 families mentioned in the auction lists were found in the parish tax lists (in 1749 and in 1789) ${ }^{73}$ Combining the three elements of land use (bedrijf), profit from retail or industry (negotiatie), and profit from leases, annuities, or offices (gestaethede)), the tax or setting was expressed in monetary terms (fiscale bunder). Applying all these standards (of all households), the local tax collector divided the amount of money requested by the central government (bede) among all the households.

This combination of sources provides information about the relative socio-economic position and geographic background of the households involved. The same strategy was applied for buyers at auction who came from Erembodegem and from Alost (for the latter, by using urban tax lists). ${ }^{74}$ Again, these lists encompass all urban householders. The tax itself was based on the value of the building occupied by the householder. However, it must be stressed that the householder was not necessarily the 
house's owner. ${ }^{75}$ Thus the urban tax lists, or huisgelden, provide an overview of all residents, both owners and tenants.

\section{ENDNOTES}

1 See especially the influential contributions in J. Brewer and R. Porter eds., Consumption and the world of goods (London, 1993). More spedifically, see L. Weatherill, Consumer behavior and material culture in Britain 1660-1760 (London, 1988); C. Shammas, The pre-industrial consumer in England and America (Oxford, 1990); D. Roche, Histoire des choses banales: naissance de la consommation dans les sociétés traditionnelles (XVIIe-XIXe siècle) (Paris, 1997); A. Schuurman, J. De Vries and A. Van Der Woude eds., Aards geluk: de Nederlanders en hun spullen van 1550 tot 1850 (Amsterdam, 1997); M. Berg and H. Clifford eds., Consumers and luxury: consumer culture in Europe 1650-1850 (Manchester, 1999); and M. Berg and E. Eger eds., Luxury in the eighteenth century: debates, desires and delectable goods (Hampshire and New York, 2003).

2 Exceptions to the rule are D. Woodward, 'Swords into ploughshares: recycling in preindustrial England', Economic History Review 38 (1985), 175-91; R. Reith, 'Recycling im späten Mittelalter und der frühen Neuzeit - eine Materialsammlung', FrühneuzeitInfo 14 (2003), 47-65; and the monograph of S. Strasser, Waste and want: a social history of trash (New York, 1999), which focuses primarily on the nineteenth and twentieth centuries.

3 See for instance M. Ginsburg, 'Rags to riches: the second-hand clothes trade 1700-1978', Costume 14 (1980), 121-35; J. Styles, 'Clothing the North: the supply of non-elite clothing in the eighteenth-century North of England', Textile History $\mathbf{2 5}$ (1994), 139-66; E. Sanderson, 'Nearly new: the second-hand clothing trade in eighteenth century Edinburgh', Costume 21 (1997), 38-48; M. Lambert, 'Cast-off wearing apparel: the consumption and distribution of second-hand clothing in northern England during the long eighteenth century', Textile History 35 (2004), 1-26; and (recently) H. Deceulaer, 'Second-hand dealers in the early modern Low Countries: institutions, markets and practices', in L. Fontaine ed., Alternative exchanges: secondhand circulations from the sixteenth century to the present (New York, 2008), 13-42.

4 B. Lemire, 'Consumerism in pre-industrial and early industrial England: the trade in second-hand clothes', Journal of British Studies 27 (1988), 1-24, 'Peddling fashion: salesmen, pawnbrokers, tailors, thieves and the second-hand clothes trade in England, c. 1700-1800', Textile History 22 (1991), 67-82, 'Second-hand beaux and "red-armed belles": conflict and the creation of fashions in England, c. 1660-1800', Continuity and Change 15 (2000), 391-417; and recently her 'Shifting currency: the culture and economy of second-hand trade in England, c. 1600-1850', in A. Palmer and H. Clark eds., Old clothes, new looks: second hand fashion (Oxford and New York, 2005), 29-48.

5 B. Lemire, 'The theft of clothes and popular consumerism in early modern England', Journal of Social History 24 (1990), 255-76; M. Vanbellinghen, 'Diefstal en heling van kleding en textiel: Antwerpen, 1775-1785', Tijdschrift voor Sociale Geschiedenis 21 (1995), 385-405; P. Allerston, 'Le marché d'occasion à Venise aux XVIe-XVIIe siècles', in J. Bottin and N. Pellegrin eds., Echanges et cultures textiles dans l'Europe préindustrielle (Lille, 1996), 15-29, and 'Reconstructing the second-hand clothes trade in sixteenth- and seventeenth-century Venice', Costume 33 (1999), 46-56; H. Deceulaer, 'Urban artisans and their countryside customers: different interactions between town 
and hinterland in Antwerp, Brussels and Ghent (18th century)', in B. Blondé, E. Vanhaute and M. Galand eds., Labour and labour markets between town and countryside (Middle Ages-19th century) (Turnhout, 2001), 218-35; C. C. Frick, 'The Florentine "Rigattieri": second hand clothing dealers and the circulation of goods in the Renaissance', in Palmer and Clark eds., Old clothes, new looks, 13-28; and I. Van Damme, 'Changing consumer preferences and evolutions in retailing: buying and selling consumer durables in Antwerp (c. 1648-c. 1748)', in B. Blondé, P. Stabel, J. Stobart and I. Van Damme eds., Buyers and sellers: retail circuits and practices in medieval and early modern Europe (Turnhout, 2006), 199-223.

6 See, however, the recent volume of Fontaine ed., Alternative exchanges. See also two recent articles in Blondé et al. eds., Buyers and sellers: J. Stobart, 'Clothes, cabinets and carriages: second-hand dealing in eighteenth-century England' (pp. 225-44), and B. Lemire, 'Plebeian commercial circuits and everyday material exchange in England, c. $1600-1900$ ' (pp. 245-66).

7 Similar remarks are to be found in S. Pennell, 'Consumption and consumerism in early modern England', The Historical Journal 42 (1999), 557 and 560, and in I. Kopytoff, 'The cultural biography of things: commodification as a process', in A. Appadurai ed., The social life of things (Cambridge, 1986), 64-94.

8 It is interesting that aspects of reuse and repair of goods were hardly touched upon in influential accounts such as F. Mendels, 'Proto-industrialiation: the first phase of the industrialisation process', Journal of Economic History 32 (1972), 241-61, or in H. Medick, 'The proto-industrial family economy: the structural function of household and family during the transition from peasant society to industrial capitalism', Social History 1 (1976), 291-315, or in P. Kriedte, H. Medick and J. Schlumbohm, Industrialization before industrialization: rural industry in the genesis of capitalism (Cambridge, 1981), 64-73.

9 E. Thoen, "A "commercial survival economy" in evolution: the Flemish countryside and the transition to capitalism (Middle Ages-19th century)', in P. Hoppenbrouwers and J. L. Van Zanden eds., Peasants into farmers? The transformation of rural economy and society in the Low Countries (Middle Ages-19th century) in light of the Brenner debate (Turnhout, 2001), 146. See, however, H. Deceulaer, 'Between medieval continuities and early modern change: proto-industrialization and consumption in the Southern Low Countries (1300-1800)', Textile History 37 (2006), 133-6.

10 Thoen, 'A “commercial survival economy" in evolution', 116, and R. Vermoesen, 'Entrepreneur versus spinner: spinsters, hun plaats in de markt en het huishouden: Regio Aalst, 1650-1800', Het Land van Aalst 58 (2006), 293-301.

11 See for instance L. Fontaine and J. Schlumbohm, 'Household strategies for survival: an introduction', in L. Fontaine and J. Schlumbohm, Household strategies for survival 1600-2000: Fission, faction and cooperation, supplement to International Review of Social History 8 (Cambridge, 2000), 1-17; and M. Overton, J. Whittle, D. Dean and A. Hann eds., Production and consumption in English households, 1600-1750 (London and New York, 2004).

12 See G. Libbrecht, 'Materiële cultuur in het 18de-eeuwse Aalst: een verkenning op het terrein van slaapcultuur, eet- en drinkcultuur, keukengerei, meubilair, decoratie, hygiëne, verwarming en verlichting', unpublished Master's dissertation, Free University of Brussels, 1997, 10-27. Different from the timing of probate inventories, however, public auctions could also take place after a bankruptcy or simply on the demand of an individual seller (of wood, paintings, trading stocks, household belongings, and so on). For this article, we have analysed only the public auctions of the goods of deceased. A possible additional research strategy, comparing wills, was unfortunately not 
possible: only those in the upper rural class made wills and only a few of these survive to today.

13 See Costumen van de Twee Steden ende Lande van Aelst, bij haer-lieden Hoogheden gedecreteert den 12 Mey 1618, ende in desen druck van vele Decreten en Reglementen verrykt (Ghent, 1771), 125 and 129.

14 Compare with J. De Vries, 'Between purchasing power and the world of goods: understanding the household economy in early modern Europe', in Brewer and Porter eds., Consumption and the world of goods, 104-6.

15 Buyers had to pay the ' $20^{\mathrm{e}}$ penning' or a 5 per cent tax on all items sold. Goods bought by heirs, on the other hand, were listed in the probate inventory and were tax-free.

16 A general study on all the intricacies of the bequeathing system in Flanders is lacking for the moment. See, however, L. De Kezel, 'Grondbezit in Vlaanderen 1750-1850: bijdrage tot de discussie over de sociaal-economische ontwikkeling op het Vlaamse platteland', Tijdschrift voor Sociale Geschiedenis 14 (1988), 61-102.

17 See also A. Matchette, 'To have and have not: the disposal of household furnishings in Florence', Renaissance Studies 20 (2006), 701-16.

18 These are located in the Municipal Archives Alost (MAA), Oud Archief Erembodegem, Staten van goed, nrs 1369-78 and 1404-13. Note that in the rest of this article we refer to the periods $1750-1759$ and 1785-1794 as 'in the 1750s' or 'around 1790' as a form of shorthand.

19 See the Appendix at the end of this article for fuller methodological coverage.

20 For instance see J. De Vries, 'Peasant demand patterns and economic development: Friesland 1550-1750', in W. N. Parker ed., European peasants and their markets: essays in agrarian economic history (Princeton, 1975), 205-66; or B. Blondé, 'Cities in decline and the dawn of a consumer society: Antwerp in the 17th-18th centuries', in B. Blondé, E. Briot, N. Coquery and L. Van Aert eds., Retailers and consumer changes in early modern Europe: England, France, Italy and the Low Countries (Tours, 2005), 37-52.

21 The small product category 'others' included one rudder and eight (fire?)locks or guns (around 1750) and, around 1790 three auction lots of books and again three sorts of gun.

22 In absolute numbers we noticed a decrease from 1,249 auction lots in this period around 1750 to 895 at the end of the eighteenth century; the total value of all transactions was also declining: from 1960.25 guilders to 1304.25 guilders around 1790 .

23 The total population of Erembodgem was continuously increasing during most of the early modern period. Around 1600 it was a small hamlet with 835 inhabitants but a century later Erembodegem boasted some 1,538 people. Around 1750, the total population figure was 1,900 , and at the end of the century 2,215. See Vermoesen, 'Entrepreneur versus spinner', 293-301.

24 At the middle of the eighteenth century, these items were already widespread in the nearby urban areas of the southern Netherlands. See for instance H. Soly, 'Materiële cultuur te Gent in de 18e eeuw: een terreinverkenning', Oostvlaamse Zanten 63 (1988), 3-15; and B. Blondé, 'Tableware and changing consumer patterns: dynamics of material culture in Antwerp, 17th-18th centuries', in J. Veeckman ed., Majolica and glass, from Italy to Antwerp and beyond: the transfer of technology in the 16th-early 17th century (Antwerp, 2002), 295-311. (A 'chimney cloth' was a piece of cloth used to decorate a mantelpiece over a fireplace.)

25 See for instance D. Helmers, 'Gescheurde bedden': oplossingen voor gestrande huwelijken, Amsterdam 1753-1810 (Hilversum, 2002).

26 For instance MAA, Oud Archief Aalst, Staten van goed, nr. 1372: 'Actum binnen Eerembodegem' (dated 9 May 1753): 'Conditien op de welcke men wettelyck ende 
publicquelijck aende meestbiedende ... sal vercoopen de naervolghende meubilaire effecten' ('Conditions regarding the legal and public sales of the following moveables'). The highest bidder was the person who received a clearly audible signal (klopslagh) from the auction official. In case of a dispute, the local authorities would judge the case. Buyers had to pay for their purchases in current currencies within a period of six weeks; a local 'policeman' (the meyer or bailliu) would collect the money. Furthermore, the highest bidder was obliged to pay immediately, 'on the table', some small local taxes (such as a twintighsten (20e) penninck or the wijngeld). Also he had to declare the names of familiar and trustworthy guarantors within the local jurisdiction (goeden ende souffisante borgen ... binnen desen vierschare justiciabel). If a financial dispute should arise, the auctioned item would be confiscated and resold. If, as a consequence, the same product fetched a lower price in a subsequent auction, the guarantors had to pay the difference.

27 For more information about this office, see Costumen van de Twee Steden ende Lande van Aelst, 42.

28 Originally the local auctioneer earned a fixed salary for his activities (XII schellingen parisis van 't pond groot, or 3.6 guilders). In the course of the seventeenth and eighteenth centuries, however, the local authorities had probably farmed this office out. This arguably gave the stockslager some freedom in settling his earnings, probably a fixed percentage on the value of the auctioned goods.

29 I. Van Damme, Verleiden en verkopen: Antwerpse kleinhandelaars en hun klanten in tijden van crisis (Amsterdam, 2007), 176-7.

30 We devised these economic categories of household based on the median value of the tax lists $(1750 \mathrm{~s}=10.75$ guilders and around $1790=7$ guilders $)$. In the $1750 \mathrm{~s}$, household category I: 0-5.374 guilders; II: 5.375-10.74; III: 10.75-16.124; IV: 16.125 and more. Around 1790, I: 0-3.4 guilders; II: $3.5-6.9$ guilders; III : 7-10.4 guilders; IV: 10.5 and over.

31 To give an idea of the economic activities of the households studied, we analysed the capital goods and the accounts mentioned in the probate inventories of the deceased. These indicators reveal to a certain degree the professional activities of the late owners. Every single household was more or less active in agriculture. In both samples, only a few households possessed horses, carts and ploughs: 16 per cent in the 1750s and 12.5 per cent around 1790. On the other hand almost 90 per cent in the 1750s and 92 per cent around 1790 had some cattle. Around 68 per cent in the 1750s and 67 per cent around 1790 cultivated hops and only 41 per cent in the 1750s and 54 per cent around 1790 grew flax, both commercial produce. Flax-processing and -spinning were quite popular activities; in both samples more than 9 out of 10 households contained capital goods involved in the processing of flax, and 96 per cent in the 1750s and 75 per cent around 1790 of the probate inventories mention spinning wheels, but only 20 per cent of the families in the 1750 s possessed a loom, a number that decreased towards the end of the eighteenth century. Around 1790 only one inventory counted a loom. Finally, the sample from around 1750 reveals some additional activities of two households: one family had a large bakery and in another household the father was also a churchwarden. There were also two aldermen who possessed horses, ploughs, and carts. Our second sample, from the end of the eighteenth century, contained two bakers and a carpenter. On the local economy of Erembodegem, see Vermoesen, 'Entrepreneur versus spinner', 293-301.

32 MAA, Oud Archief Erembodegem, Settingen, nrs 251 and 255; D. Meert, Gezinstoestand te Erembodegem tussen 1731 en 1765 (n.p., n.d.).

33 See also Meert, Gezinstoestand. 
34 The setting of 1789 mentions 460 households.

35 Stobart, 'Clothes, cabinets and carriages', 230; Van Damme, Verleiden en verkopen, 68.

36 N. Gregson and L. Crewe, Second-hand cultures (Oxford and New York, 2003), 3-4. See also Stobart, 'Clothes, cabinets and carriages', who uses the same motivations in his analysis (pp. 232-6).

37 Stobart, 'Clothes, cabinets and carriages', 234.

38 B. Lemire, Fashion's favourite: the cotton trade and the consumer in Britain, 1660-1800 (Oxford, 1991), 62.

39 Unpublished database, based on MAA, Oud Archief Erembodegem, Staten van goed, nrs 1369-78 and 1404-13.

40 See D. Donald, The age of caricature: satirical prints in the reign of Geoge III (New Haven and London, 1996), 82-3.

41 I. Van Damme, 'Zotte verwaandheid: over Franse verleiding en Zuid-Nederlands onbehagen, $1650-1750$ ', in R. de Bont and T. Verschaffel eds., Het verderf van Parijs (Louvain, 2004), 187-203.

42 Expensive 'older' products like paintings, books, and antiquities were bought as a result of relatively new, emerging motivations such as building a prestigious collection of 'things'. Buying these 'second-hands', however, also links to categories of constructing self-identity and social status through consumption; see S. Nenandic, 'Romanticism and the urge to consume in the first half of the nineteenth century', in Berg and Clifford eds., Consumers and luxury, 208-27.

43 See also Stobart, 'Clothes, cabinets and carriages', 233.

$44 \mathrm{~J}$. Savary, Le parfait négociant ou instruction générale pour ce qui regarde le commerce des marchandises de France \& des Pays Etrangers (second edn, Paris, 1749), vol. 1, 111.

45 Only in urban centres did the wealthy few began to refurbish their homes in frequent succession, a task executed by increasingly important professionals, such as the $u p$ holder or marchand mercier. For more context, see B. Blondé and I. Van Damme, 'Een crisis als uitdaging? Kleinhandelsevoluties en verbruiksveranderingen te Antwerpen (ca. 1648-ca. 1748)', Tijdschrift voor Sociale en Economische Geschiedenis 4 (2007), 76-81; C. Sargentson, 'The manufacture and marketing of luxury goods: the marchands merciers of late 17th- and 18th-century Paris', in R. Fox and A. Turner eds., Luxury trades and consumerism in ancien régime Paris: studies in the history of the skilled workforce (Aldershot, 1998), 112-13, 116-17 and 120-1; M. Craske and M. Berg, 'Art and industry - the making of modern luxury in eighteenth-century Britain', in S. Cavachiocchi ed., Economia e arte secc. XIII-XVIII (Florence, 2002), 833; and C. Edwards, 'The upholster and the retailing of domestic furnishings 1600-1800', in Blondé et al. eds., Retailers and consumer changes, 53-69.

46 Also remarked by Stobart, in 'Clothes, cabinets and carriages', 242.

47 In this respect, the model described in P. Stabel, 'Town and countryside in the Southern Low Countries in the late 15th-early 19th century: preliminary reflections upon changing relations in the pre-industrial economy', in R. Ni Néill ed., Town and countryside in Western Europe from 1500-1939 (Leicester, 1996), 1-27, should be modified.

48 For more information about retailers from Alost, see S. De Schryver, 'De Aalsterse ambachten vanuit een sociaal-economische invalshoek (achttiende eeuw)', Het Land van Aalst 54 (2002), 113-52.

49 Unpublished database based on MAA, Oud Archief Erembodegem, Staten van goed, nrs 1369-78 and 1404-13.

50 MAA, Oud Archief Aalst, Staten van Goed, nr 1868, Margerita Geldof 1752; Huisgelden, $\mathrm{nr} 273$. 
51 See P. Clark, The English alehouse: a social history, 1200-1830 (London, 1983); G. Rooijakkers, 'Opereren op het snijpunt van culturen: Middelaars en media in ZuidNederland', in P. te Boekhurst, P. Burke, en W. Frijhoff eds., Cultuur en Maatschappij in Nederland, 1500-1850: een historisch-antropologisch perspectief (Heerlen, 1992), 249; B. Kümin, 'Useful to have, but difficult to govern: inns and taverns in Early Modern Bern and Vaud', Journal of Early Modern History 1 (1997), 153-75; R. Britnell, 'Markets, shops, inns, taverns and private houses in medieval English trade', in Blondé et al. eds., Buyers and sellers, 109-23; Van Damme, Verleiden en verkopen, 85-6;

52 MAA, Oud Archief Aalst, Winkeliers en kramers, nr 217. See also S. De Schryver, 'Aspecten van sociale mobiliteit binnen de 18de eeuwse Aalsterse ambachtswereld: een prosopografische benadering', unpublished Master's dissertation, Ghent University, 2002; and De Schryver, 'De Aalsterse ambachten', 113-52. The four remaining buyers from Alost were probably related to the deceased owners of the auctioned possessions.

53 More information about ambulant tradesmen in the Low Countries can be found in H. Deceulaer, 'Dealing with diversity: pedlars in the Southern Netherlands in the eighteenth century', in Blondé et al. eds., Buyers and sellers, 171-98.

54 For this early industrial activity in and around the nearby city of Aalst, see L. De Rijck, 'Kenmerken van de industriële ontwikkeling te Aalst (1795-1875)', Handelingen der Maatschappij voor Geschiedenis en Oudheidkunde te Gent. Nieuwe Reeks 18 (1964), 1-19, and Vermoesen, 'Entrepreneur versus spinner', 293-301.

55 Gregson and Crewe, Second-hand cultures, 11.

56 G. McCraken, Culture and consumption: new approaches to the symbolic character of consumer goods and activities (Bloomington, 1988), 87-8; Gregson and Crewe, Secondhand cultures, $155-63$.

57 R. Sarti, Europe at home: family and material culture, 1500-1800 (New Haven, 2002), 45-8 and 119-23.

58 See also Shammas, The pre-industrial consumer, 197-223.

59 Woodward, 'Swords into ploughshares', 176.

60 From his The theory of moral sentiments, quoed in Berg and Clifford eds., Consumers and luxury, 10.

61 See C. Shammas, 'The decline of textile prices in England and British America prior to industrialisation', Economic History Review 48 (1994), 483-507, and more generally P. Musgrave, The early modern European economy (New York, 1999), 61-6.

62 See for instance J. Styles, 'Manufacturing, consumption and design in eighteenthcentury England', in Brewer and Porter eds., World of goods, 543: 'goods that missed the latest fashion trend could not be easily sold'; or S. Nenadic, 'Middle-rank consumers and domestic culture in Edinburgh and Glasgow 1720-1840', Past and Present 145 (1994), 134, who stresses the declining marketing potential of the second-hand for similar reasons.

63 See De Vries, 'Between purchasing power and the world of goods', 101, and Blondé and Van Damme, 'Een crisis als uitdaging?', 83-6.

64 D. Roche, Le peuple de Paris: essai sur la culture populaire au XVIIIe siècle (Paris, 1998), 222-3; see also P. Verlet, 'Le commerce des objets d'art et les marchands merciers à Paris au XVIIIe siècle', Annales: Économies, Sociétés, Civilisations 13 (1958), 28: 'Les ventes publiques prennent au XVIIIe siècle de l'extension.'

65 R. Vermoesen, 'Markttoegang en commerciële netwerken van rurale huishoudens', unpublished doctoral dissertation, University of Antwerp, 2008 (publication forthcoming). Use of earthenware goods in the kitchens of rural households around Alost was gradually disappearing. Around 175080 per cent of all households owned earthenware products; half a century later this percentage had dropped to 68 per cent. 
66 In the kitchens of rural households around Alost too, the percentage of pewter goods dropped but less significantly, from 43 per cent around 1750 to 37 per cent at the end of the eighteenth century. See again Vermoesen, 'Markttoegang'.

67 See, however, N. Coquery, 'The language of success: marketing and distributing semiluxury goods in eighteenth-century Paris', Journal of Design History 17 (2004), 87; K. De Vlieger-De Wilde, Adellijke levensstijl: dienstpersoneel, consumptie en materiële leefwereld van Jan van Brouchoven en Maria Livina de Beer, graaf en gravin Van Bergeyck (ca. 1685-1740) (Brussels, 2005), 126-46; C. De Staelen, 'Levenswijze en consumptiepatroon van een Antwerpse weduwe. Het huishoudjournaal van Elisabeth Moretus (1664-1675)', unpublished Master's dissertation, Ghent University, 2002, 136-7 and 139 .

68 See N. McKendrick, J. Brewer and J. H. Plumb, The birth of a consumer society: the commercialization of eighteenth-century England (London, 1982).

69 See C. Campbell, The romantic ethic and the spirit of consumerism (Oxford, 1987).

70 As is, indeed, confirmed by research stressing the so-called paradox of demand in confronting probate inventories with the evolutions of prices and wages. See, most importantly, J. De Vries, The industrious revolution: consumer behaviour and the household economy (Cambridge, 2008).

71 See note 18, above. See also H. Van Isterdael and F. Caudron, Aangiften van nalatenschap, kavelingen en wezenrekeningen van de meierij Erembodegem (Erembodegem, Welle, Iddergem en Teralfene), daarna de heerlijkheid Erembodegem-Teralfene (15801798), Rijksarchief te Beveren: toegang in beperkte oplage, 281 (Brussels, 2004), 158-68 and $277-88$.

72 See also Meert, Gezinstoestand, and D. Meert, Alfabetisch repertorium van de families te Erembodegem 1591-1880 (Erembodegem, 1999).

73 MAA, Oud Archief Erembodegem, Settingen, nrs 251 en 255.

74 MAA, Oud Archief Aalst, Huisgelden, nrs 264-82.

75 R. Vermoesen, 'Welvaart en ongelijkheid in een achttiende-eeuwse kleine stad', Het Land van Aalst 60 (2008), 54-63. 